\title{
CONSENT DECREES AND THE PRIVATE ACTION: AN ANTITRUST DILEMMA
}

The consent decree ${ }^{1}$ and the private right of action ${ }^{2}$ are two methods recognized by the Clayton Act ${ }^{3}$ for the enforcement of the federal antitrust laws. ${ }^{4}$ Section 5(a) of the Clayton Act provides that a judgment or decree obtained by the Government in an antitrust proceeding, except a consent decree, may be used as prima facie evidence of an antitrust violation in a private suit. ${ }^{5}$ Successful prosecution of a private antitrust

1 The consent decree is an agreement achieved through negotiations between the antitrust division of the Justice Department and the defendant charged with the violation. The negotiated decree has the same effect as a litigated decree, binding both the Government and the consenting defendant to its terms. United States v. International Harvester Co., 274 U.S. 693 (1927); Swift \& Co. v. United States, 276 U.S. 311 (1928). There is no express statutory authorization of the use of the consent decree for enforcing the antitrust laws; its use is recognized, however, by the proviso of $\S 5(a)$ of the Clayton Act, 38 Stat. 731 (1914), as amended, 15 U.S.C. \& 16(a) (1958). For text of this section see note 5 infra.

For a discussion of consent decrees in general, see Note, 72 HaRv. L. REv. 1314 (1959). For analyses of the consent decree program in antitrust enforcement, see Gordberg, THE Consent Decree: ITS Forarulation and USE (1962) [hereinafter cited as Goldberc]; Phillips, The Consent Decree in Antitrust Enforcement, 18 WASH. \& LEE L. REV. 39 (1961); Peterson, Consent Decrees: A Weapon of Anti-Trust Enforcement, 18 U. of Karss. Ciry L. REv. 34 (1950); Isenburgh \& Rubin, Antitrust Enforcement Through Consent Decrees, 53 Harv. L. Rev. 386 (1940); Katz, The Consent Decree in Antitrust Enforcement, 53 HaRv. L. Rev. 415 (1940); Donovan \& McAllister, Consent Decrees in the Enforcement of Federal Anti-Trust Laws, 46 HARv. L. REv. 885 (1933).

2 Clayton Act $\S 4,38$ Stat. 731 (1914), 15 U.S.C. § 15 (1958).

338 Stat. 730 (1914), as amended, 15 U.S.C. §§ 12, 13, 14-27 (1958), as amended, 15 U.S.C. §§ 13, 21 (Supp. V, 1964).

4 The Clayton Act § 1, 38 Stat. 730 (1914), 15 U.S.C. § 12 (1958) defines antitrust Jaws as: The Sherman Anti-Trust Act, 26 Stat. 209 (1890), 15 U.S.C. \$§ 1-7 (1958); Wilson Tariff Act $\$ \S 73-77,28$ Stat. 570 (1894), as amended 15 U.S.C. $\S \S 8-11$ (1958); and the Clayton Act, supra note 3.

5 "A final judgment or decree heretofore or hereafter rendered in any civil or criminal proceeding brought by or on behalf of the United States under the antitrust laws to the effect that a defendant has violated said laws shall be prima facie evidence against such defendant in any action or proceeding brought by any other party against such defendant under said laws . . . as to all matters respecting which said judgment or decree would be an estoppel as between the parties thereto: Provided, That this section shall not apply to consent judgments or decrees entered before any tstimony has been taken. . .." 69 Stat. 283 (1955), 15 U.S.C. \$§ 16(a) (1958). Section 5(a) also excepts judgments in favor of the Government in actions to recover for injuries to the Government's business or property as a result of an antitrust violation. 69 Stat. 282 (1955), 15 U.S.C. 15a (1958). Most government civil antitrust actions-those which this comment discusses-are equity proceedings brought to enjoin illegal business practices.

Whether a cease and desist order issued by the Federal Trade Commission is a $\& 5$ (a) judgment may be considered by the Supreme Court during the current term. See New Jersey Wood Finishing Co. v Minnesota Mining \& Mfg. Co., 332 F.2d 346 (3d Cir.), cert. granted, 379 U.S. 877 (1964) (FTC order is a section 5(a) judgment) (alternative holding). But see Highland Supply Corp. v. Reynolds Metals Co., 327 F.2d 725 (8th Cir. 1964); 
suit $^{6}$ frequently depends upon the availability of a government judgment as prima facie evidence. ${ }^{7}$ If the Government enters into a consent decree, that evidence is unavailable. Consequently, the consent decree and the private action are often mutually exclusive.

The Attorney General, charged with responsibility for enforcement of the antitrust laws, often obtains injunctive relief through use of the consent decree. ${ }^{8}$ Although entered as a judgment of the court, a consent decree is generally the result of informal negotiations between a defendant and the Justice Department's antitrust division. ${ }^{\circ}$ Thus, when negotiating with a defendant, the antitrust division's position is analogous to that of a regulatory agency ${ }^{10}$ in that it must determine whether a

Farmington Dowel Prod. Co. v. Forster Mfg. Co., 223 F. Supp. 967 (D. Me. 1963); Volasco Prod. Co. v. Lloyd A. Fry Roofing Co., 223 F. Supp. 712 (E.D. Tenn. 1963). The principal issue is whether an FTC hearing comes within the statutory language "civil proceeding." An administrative hearing ordinarily is not considered to be a civil proceeding. It does not seem logical, however, to distinguish between a Justice Department action and an FTC proceeding when both would decide essentially the same issues. It could be argued, however, that because of more liberal evidentiary rules of the administrative proceeding, an FTC order is inappropriate as a $\S 5(\mathrm{a})$ "judgment." Perhaps the more liberal evidentiary rules should go only to the evidentiary weight to be given an FTC order rather than to its admissibility. Allowing utilization of an FTC order as evidence-if the order is not a consent decreeappears consistent with allowing private actions based on administrative regulations. See J. I. Case Co. v. Borak, 377 U.S. 426 (1964). See generally Matteoni, An Antitrust Argument: Whether a Federal Trade Commission Order is Within the Ambit of the Clayton Act's Section 5, 40 Notre DaMe Law. 158 (1965).

"As hereinafter used, the term "private litigants" refers to any party entitled to bring a treble damage action pursuant to $\S 4$ of the Clayton Act. See note 2 supra. The term includes states, Georgia v. Evans, 316 U.S. 159 (1942), and municipalities, Chattanooga Foundry and Pipe Works v. City of Atlanta, 203 U.S. 390 (1906).

7 "It has been estimated that approximately three-fourths of all private suits have followed in the wake of victorious government actions in fully litigated cases. . . . The almost inevitable consequence of the acceptance of a consent decree by the Justice Department . . . is to deprive private suitors, who have been injured by unlawful conduct, of their statutory remedies under tbe antitrust laws." SUBCOMOM. No. 5, HOUSE COMOs. ON THE Judiciary, 86th Cong., 1st Sess., Report on Consent Decree Program of the DepartMAENT OF JUSTICE (Comm. Print 1959). [hereinafter cited as House REPORT].

Recently, however, a considerable number of private actions have been instituted without the benefit of a prior government proceeding. These actions primarily have concerned business relations between dealers or distributors and their suppliers. See, e.g., Klor's Inc. v. Broadway-Hale Stores, Inc. 359 U.S. 207 (1959); Osborn v. Sinclair Ref. Co., 286 F.2d 832 (4th Cir. 1961), cert. denied, 366 U.S. 963 (1961); of. Radiant Burners, Inc. v. Peoples Gas, Light \& Coke Co., 364 U.S. 656 (1961).

$8 \mathrm{Mr}$. William Orrick, Assistant Attorney General in charge of the Justice Department's antitrust division, estimates that currently about $80 \%$ of the Government's civil complaints are settled by consent decrees. From 1935 to 1952, the percentage was 72\%, ATT'y GEN. NaT't Comar. Antitrust REP. 360 (1955), and rose to above $80 \%$ in the latter part of the 1950's. HOUSE REPORT 8.

${ }^{9}$ See Timberg, Recent Developments in Antitrust Consent Judgments, 10 FED. B.J. 351 (1949).

${ }^{10}$ Ibid. 
proposed consent decree provides the injunctive relief necessary for the public interest. ${ }^{11}$ Additionally, the division's decision to accept or reject a proposed consent decree involves consideration of the many practical difficulties that plenary litigation entails: problems of proof, uncertainty of outcome, and allocation of government personnel among a multitude of demands.

This Comment, in parts I and II, explores ways in which the Government can seek to protect private parties from two potential detriments of a consent decree: inadequate injunctive relief and effective foreclosure of a private action. Part III examines two means by which private litigants may be able to derive benefit from a government action notwithstanding the entry of a consent decree. These are the use of government procured contempt judgments and the use of the fruits of discovery from a government prosecuted action.

I

ATTEMPTS TO ASSURE ADEQUATE INJUNCTIVE RELIEF

Consent decrees may lack the injunctive relief necessary to protect third parties dealing with the defendants. Failure to provide adequate relief could result either from judicially imposed limitations upon the Government's demands in consent decree negotiations or, to a lesser extent, from inadequate channels of communication between the Government and third parties who have busmess dealimgs with the defendant. Subpart A of this section examines the limitations on trial court interference with consent decree negotiations. Subpart B surveys the possibilities for modifications of a consent decree in order to obtain further relief. Subpart $C$ discusses attempts that have been made to prevent entry of a consent decree which lacks adequate relief.

\section{A. Judicial Interference with Consent Decree Negotiations}

If the Justice Department believes that a defendant's proposal for a consent decree requires additional provisions for relief, the Department may choose to withhold its consent. The defendant is then presumably forced either to hitigate - and risk an adverse judgment-or to incorporate adequate provisions for rehef in the proposed decree.

In an attempt to circumvent such a dilemina, the defendants in United States v. Ward Baking ${ }^{12}$ moved for entry of a decree to which the Government had not consented. The defendants had been charged with conspiring to allocate among themselves the supplying of bakery 
products to certain naval installations by submitting collusively rigged bids. During consent decree negotiations, the Government and the defendants had agreed on provisions enjoining the alleged practices. The Government insisted, however, on extending the injunction to price fixing on bakery sales to third parties other than the United States. This insistence led the trial court to enter a "consent decree" over the Government's objection. ${ }^{13}$ The court, though it made no findings of fact, held that the Government's demands were "arbitrary and unauthorized."

In reversing and remanding for trial, the Supreme Court held that, "where the Government seeks an item of relief to which evidence adduced at trial may show that it is entitled,"14 the trial court may not enter a consent decree without the Government's consent. ${ }^{10}$ The Court noted that the record before the trial court showed four of the five defendants had previously pleaded nolo contendere to charges of conspiratorial price fixing on nongovernment sales. This history convinced the Court that a trial might have shown that the injunctive relief demanded by the Government was justified.

The absence of a sufficiently detailed record-the situation in Ward Baking-generally makes inappropriate the entry of a "consent" decree without the Government's consent. ${ }^{16}$ The factual issues in an antitrust action are typically complex because the economic effects of the defendant's practices are difficult to determine and subject to dispute. Consent decree negotiations take place outside the trial judge's presence; ${ }^{17}$ consequently, apart from the moving party's allegations and the facts stipulated, the trial court generally has hittle information froin which it can determine the necessary relief. Moreover, a judgment based on a decree to which only one party has consented is comparable to a summary judgment: Unlike a decree wherein both parties consent, the nonconsenting party has the right to appeal. ${ }^{18}$ Yet review $^{10}$ is possible only

13 United States v. Ward Baking Co., 1963 Trade Cas. 77, 499 (M.D. Fla. 1963).

14376 U.S. at 344. (Emphasis added.)

15 The decision provides further support for the comparison between the Justice Department in consent decree negotiations and the regulatory agencies. See Timberg, supra note 9. The courts generally defer to the Federal Trade Commission's provisions for relief though the conduct enjoined may range far beyond that which constituted the alleged violation. See FTC v. Henry Broch \& Co. 368 U.S. 360 (1962); Coro, Inc. v. FTC, 338 F.2d 149 (1st Cir. 1964), petition for cert. filed, 33 U.S.L. WeEK 3275 (U.S. Feb. 16, 1965) (No. 885).

16376 U.S. at 331; United States v. Hartford-Empire Co., 1 F.R.D. 424 (N.D. Ohio 1940).

17 Phillips, The Consent Decree in Antitrust Enforcement, 18 WASH. \& LEE L. REv. 39, 41 (1961).

18 Swift \& Co. v. United States, 276 U.S. 311 (1928).

19 Appeals from judgments in Government civil antitrust proceedings are taken directly 
with a sufficiently detailed record from which the appellate court can determine whether the relief provided is appropriate. For instance, if it is believed necessary, an act which itself is legal may be enjoined to prevent the defendant from enjoying the fruits of his illegal conduct. ${ }^{20}$ But an appellate court, without a record detailing the defendant's activities and the consequences of those activities would be unable to determine whether relief beyond that barring the allegedly illegal conduct is justified. ${ }^{21}$ Ward Baking appears to require an indisputable showing of fact and reason justifying the entry of a decree without the Government's consent.

The pre-trial conference had been used, prior to Ward Baking, to determine whether the relief demanded by the Government was "justified." In United States v. Standard Oil Co., ${ }^{22}$ consent decree negotiations had reached an impasse because of the Government's demand that the defendants be enjoined from certain retailing activities. The court directed the parties to submit detailed statements along with factual information supporting their contentions. At a pre-trial hearing, the Government generally conceded the accuracy of the defendants' showing as to the post-complaint marketing conditions. The court decided, based on the defendants' showing, that even if the Government proved violations had occurred prior to the filing of the complaint, the disputed relief was no longer justified because of changed competitive conditions. The Government dropped the demand and a consent decree was subsequently entered. ${ }^{23}$

The advantage of a pre-trial hearing comparable to that in Standard Oil is its tendency to mitigate "arbitrary" governmental demands for relief. Use of pre-trial hearings in this manner, however, presents problems. First, extending Standard Oil to permit application for a hearing

to the Supreme Court pursuant to $\S 2$ of the Expediting Act, 62 Stat. 989 (1948), 15 U.S.C. \& 29 (1958).

20 International Salt Co. v. Umited States, 332 U.S. 392, 400 (1947).

21 The Supreme Court has stressed the importance of the trial court's function of providing adequate injunctive relief after resolution of the factual dispute. See United States v. United States Gypsum Co., 340 U.S. 76, 89 (1950); International Salt Co. v. United States, 332 U.S. 392, 400-01 (1947). The Court, however, does review the record closely and, on occasion has reversed the trial court's rehef provisions. See, e.g., United States v. United States Gypsum Co., 340 U.S. 76 (1950); Hartford-Empire Co. v. United States, 323 U.S. 386 (1945).

221959 Trade Cas. 75,522 (S.D. Cal. 1959). Subsequent investigations were made to determine the effect this consent decree had on third parties. See Select Committee on Small Business, Operation and Effect of Consent Decree in West Coast Oil Case, H.R. REP. No. 2522, 87th Cong., 2d Sess. (1962).

23 The trial court, apparently recognizing the importance of not removing the consent decree from the $\S 5(\mathrm{a})$ provisio, emphasized that the pre-trial procedure had not been a part of a trial nor had there been any testimony introduced. 
each time a defendant believed the Government's demands were onerous would disrupt consent decree negotiations. The defendant would liave nothing to lose by applying for a liearing. If the judge determined the relief demanded was unreasonable, the Government would probably be discouraged from forcing a trial on that issue. Second, the Government might argue that judicial interference with consent decree negotiations weakens its bargaining power. Uncertainty as to the extent of relief that will be granted after full litigation may provide the Government with flexibility in bargaining. ${ }^{24}$ Moreover, the advantage a pre-trial learing affords a defendant may be offset by detriment to potential private litigants. In Standard Oil for example, had the court decided that the relief demanded by the Government was reasonable, the defendants would have liad the advantage of knowing that determination without trial, and consequently without risking the potential detriment of trial: an adverse judgment available as prima facie evidence in subsequent private actions. Of course, if section 5(a) of the Clayton Act is designed to encourage consent decrees rather than to aid private litigants, this advantage is justified. The parties are more likely to reach agreement on relief if they know the probable extent to whicls the court will grant the Governinent's demands.

Ward Baking appears to prohibit such use of the pre-trial hearing whenever the Government objects. The Court, discussing the problem in a footnote, stated:

[A] show-cause order [at a pre-trial conference] cannot properly be read as a demand that the Government detail or tender the evidence it proposed to offer at trial. The Government's response, which specified its legal and factual objections to the entry of the proposed decree and informed the court of [a criminal indictment against one of the defendants for a nongovernment price fixing conspiracy] ... was a full and satisfactory response to the show-cause order. ${ }^{25}$

Even without a showing comparable to that in Ward Baking, the Government in most situations should be able to slow some reasonable factual connection between the complaint's allegations and the relief demanded in consent decree negotiations. The Supreme Court thought it

$24 \mathrm{~A}$ defendant, although believing a government demand for injunctive relief is onerous, cannot know with certainty the extent of relief that will be granted by a court. Refusal to agree to certain demands might force a costly trial with the risk that the disputed relief will be granted anyway. Moreover, hitigation includes the risk of a judgment that comes within $\S 5(a)$ of the Clayton Act. A bearing comparable to that in Standard Oil reduces this uncertainty for a defendant considering the alternatives of trial or consent decree. To the extent that the defendant knows the probability that certain relief will be granted, the Government's bargaining position is weakened. See Handler, Recent Antitrust Developments-1964, 63 MICH L. REv. 59, 89 (1964).

25376 U.S. at $333-34$. 
unlikely that a trial court, as a practical matter, could determine without a hearing on the merits that Government demands were unjustified. "It would be a rare case where all the facts necessary for a trial court to decide whether a disputed item of relief was warranted could be determined without an 'opportunity to know the record.' " ${ }^{26}$ In Ward Baking, for example, if management sanctioned price fixing were proved, it would not be unreasonable to suspect similar practices by the defendants in nongovernment dealings. Evidence introduced at trial to prove price fixing on government sales could show the practice was management-sanctioned. Therefore, without a showing of the prior criminal proceedings, the disputed relief would still come within the standard set by the Court. ${ }^{27}$

Where there can be slown a logical relationship between the facts alleged and the relief demanded, Ward Baking appears to give the Government the unqualified power to force an adjudication by insisting upon injunctive provisions to which the defendant will not accede. There are, of course, barriers to the abuse that the possession of this power offers, although they may be of small coinfort to any one defendant. Those barriers include the Government's limited ability to prosecute cases because of an increasingly heavy workload, ${ }^{28}$ the difficulties of proof inherent in litigation, the potential animosity of trial courts to coercive government practices, and the ever present pressures from Congress. In a given instance, however, the Government has the discretionary power to force a trial if the defendant balks at the relief demanded. ${ }^{29}$

$26 I d$. at 331.

27 "[I]t cannot reasonably be assumed that the Government could not, at the trial, have introduced evidence justifying, in whole or in part, the relief sought." Id. at 333. Evidence admissible for determining the scope of relief is not restricted to that introduced to prove a violation. The trial court could, therefore, admit evidence relating to the defendants' dealings with other third parties once the allegations were proved. See United States v. E. I. du Pont de Nemours \& Co., 353 U.S. 586, 607 (1957); Umited States v. Umited States Gypsum Co. 340 U.S. 76, 85 (1950).

28 In 1946, with a professional staff of about 190, the antitrust division either completed or had in process 354 investigations at the end of the year. In 1954, a staff of 243 conducted 403 investigations. In 1962, there were 306 staff members for 796 investigations. See Loevinger, Antitrust in 1961 and 1962, 8 ANTItrust Bunc. 349, 377-79 (1963). See also HoUse REPORT 8.

29 Although Ward Baking arose in the procedural context of a pre-trial conference, the Court in relying on United States v. Umited States Gypsum Co., 340 U.S. 76 (1950), may have granted the Justice Departınent broad discretion in determining the scope of relief to be considered where a summary judgment has been entered against the defendant. "[The District Court] has the duty to compel action by the conspirators that will, so far as practicable, cure the ill effects of the illegal conduct, and assure the public freedom from its continuance. Such action is not limited to prohibition of the proven means by which the evil was acomplished, but may range broadly through practices connected with acts actually found to be illegal." United States v. Ward Baking, 376 U.S. at 331. Contrast Ward Baking with United States v. W. T. Grant Co., 345 U.S. 629 (1953), where the Court was 


\section{B. Modification}

Despite the trial court's retention of jurisdiction to allow, inter alia, modification of consent decrees, neither the Government ${ }^{30}$ nor defendants ${ }^{31}$ have been particularly successful in obtaining modification over the adverse party's objection. The standard set by United States $v$. Swift $\mathcal{E}$ $\mathrm{Co}^{32}$ has generally governed: "Nothing less than a clear showing of grievous wrong evoked by new and unforeseen conditions should lead us to change what was decreed ... with the consent of all concerned." ${ }^{133}$

Many consent decrees have included a clause generally providing that the Government could apply for additional relief either after a specified number of years had passed ${ }^{34}$ or where certain purposes of the consent decree had not been fulfilled..$^{35}$ Apparently, no application pursuant to such a clause has been made; consequently, the utility of the clause remains untested.

A private party might be able to utilize a modification clause by asking the Government to apply for further relief. Such a request would

first called upon to consider the Clayton Act's prohibition against interlocking directorates. The defendants had filed uncontroverted affidavits with the trial court swearing that all directorships alleged to violate the Act's prohibition had been resigned. The lower court, deciding the question was moot, entered a summary judgment for the defendants. The Supreme Court held the question was not moot; it affirmed the decision, however, holding that the Government had failed to show an abuse of discretion by the trial court. Justices Douglas and Black dissented, arguing that because the trial court failed to consider several factors relevant in determining the scope of an antitrust decree, its judgment was not entitled to the presumption of validity. Ward Baking held that where the Government seeks relief to which evidence adduced at a trial may show that it is entitled, the mere cessation of alleged violations does not justify the entry of a consent decree without the Government's consent. Grant appears to be inconsistent with Ward Baking. Where the summary judgment is entered for the Government, and the record reveals that the trial court looked beyond the alleged violations in determining the scope of relief, the Supreme Court may give more deference to the trial court's provisions. A summary judgment for the Government, unlike the judgments in Ward Baking and Grant would be available to private litigants as prima facie evidence.

30 E.g., United States v. Atlantic Ref. Co., 360 U.S. 19 (1959); United States v. International Harvester Co., 274 U.S. 693 (1927). But ef. Chrysler Corp. v. United States, 316 U.S. 556 (1942).

31 E.g., United States v. Swift \& Co., 286 U.S. 106 (1932).

32286 U.S. 106 (1932).

83 Id. at 119; See United States v. Swift \& Co, 189 F. Supp. 885 (N.D. Ill.) affd mem. 367 U.S. 909 (1961). For an exception, see Chrysler Corp. v. United States, 316 U.S. 556 (1942).

84 E.g., United States v. Columbia Artists Management, Inc., 1955 Trade Cas. 70,830 (S.D.N.Y. 1955); United States v. Kosher Butchers' Ass'n, 1955 Trade Cas. 70,206 (1955); United States v. Allied Florists Ass'n, 1953 Trade Cas. 68,167 (N.D. Ill. 1953).

35 E.g., United States v. National Cranberry Ass'n, 1957 Trade Cas. 73,442 (D. Mass. 1957) ; United States v. Minute Maid Corp., 1955 Trade Cas. 70,673 (S.D. Fla. 1955); United States v. New York Great Atl. \& Pac. Tea Co., 1954 Trade Cas. 69,110 (S.D.N.Y. 1954). 
probably be treated like any other complaint received by the antitrust division. If so, its major handicap would be the division's limited time and manpower.

If the Government does obtain additional injunctive relief pursuant to a modification clause, the modified decree is unlikely to be available as prima facie evidence to a private litigant. ${ }^{36}$ Section 5 (a) requires that a final decree be "to the effect that a defendant lias violated said antitrust laws." Even a plenary liearing on modification of relief probably would not adjudicate the question of an antitrust violation. An attempt to litigate that issue during such a hearing might encounter problems of collateral estoppel, ${ }^{37}$ jeopardize relief already provided in the consent decree, and involve a fuller presentation of evidence than would a hearing solely concerned with a proposed change in relief. The primary benefit accruing to a third party from such a hearing, therefore, would probably be additional injunctive relief.

One commentator has suggested that, in lieu of seeking modification, the Government may be able to circumvent a consent decree by instituting a new proceeding agaimst the defendant. ${ }^{38}$ A second proceeding miglit be possible because of the variety of laws pursuant to which the Government can proceed, ${ }^{39}$ the changes brought about in the business world by the passage of time, ${ }^{40}$ the reluctance of the courts to restrain the Government from prosecuting the antitrust laws, ${ }^{41}$ and the change in judicial construction of the antitrust laws. ${ }^{42}$ The Government is unlikely to pursue this course, however, because of the adverse effects such a practice could have on consent decree negotiations. ${ }^{43}$

36 Section 5(a) of the Clayton Act excepts from prima facie evidence effect only those consent decrees entered before any testimony has been taken. See note 5 supra. Arguably, testimony at a hearing on modification of relief removes the modified decree from the $\S 5$ (a) proviso. It seems likely, however, that "testimony" would be construed to mean testimony presented on the question of an antitrust violation, not relief. See United States v. Standard Oil Co., 1959 Trade Cas. 75,522 (S.D. Cal. 1959).

37 "Since these consent decrees are based upon an agreement made by the Attorney General which is binding upon the Government the defendants are entitled to set them up as a bar to any attempt by the Government to relitigate the issues raised in the suit ...." United States v. Radio Corp. of America, 46 F. Supp. 654, 656 (D. Del. 1942). Though this bar would not apply to questions arising after entry of the consent decree, the Government, if unable to introduce evidence relating to acts occurring prior to entry of the decree, might have difficulty proving particular acts illegal under the antitrust laws.

38 Dabney, Antitrust Consent Decrees: How Protective an Umbrella?, 68 YALE L.J. 1391 (1959).

39 Id. at $1400-03$

40 Id. at $1399-1400$.

41 Id. at 1403-04.

42 Compare United States v. Parke, Davis \& Co., 362 U.S. 29 (1960), with United States v. Colgate \& Co., 250 U.S. 300 (1919).

${ }^{43}$ See Dabney, supra note 38 . It seems unlikely that such government conduct would 


\section{Third Party Participation in Government Proceedings}

Third parties have generally not been permitted to intervene in government antitrust actions. ${ }^{44}$ The prohibition applies to both negotiations $^{45}$ and trial. ${ }^{46}$ Petitions to intervene have been denied where the Government favored ${ }^{47}$ as well as where it opposed ${ }^{48}$ intervention. The principal reason for rejecting a third party petition is to forestall interference with the Justice Department's control of the action. ${ }^{40}$ Also, differences in the acts sought to be proved and the rehef desired make dual prosecution of an antitrust proceeding inappropriate. ${ }^{50}$ Because of these differences, intervention would tend to increase the complexity of a suit, thus possibly jeopardizing the outcome of the Government's case.

seriously impair the consent decree program, as Dabney suggests. The alternative available to a defendant-trial with the attendant risk of a $\S 5(a)$ judgment-is unappealing. Defendants might demand, however, greater safeguards in the consent decree. These demands could result in either unnecessary Government concessions or stymied negotiations. If the parties failed to reach agreement, the Government could, if it chose, force a trial. As a practical matter, this alternative can not be pursued frequently. Limited resources curtail the Government's ability to litigate. See generally Dabney supra note 38, at 1406-07.

44 Petition to intervene denied: Sam Fox Publishing Co. v. Umited States, 366 U.S. 683 (1961); Sutplien Estates, Inc. v. United States, 342 U.S. 19 (1951); United States v. Paramount Pictures, Inc., 334 U.S. 131 (1948); Allen Calculators, Inc. v. National Cash Register Co., 322 U.S. 173 (1944); Umited States v. Radio Corp. of America, 186 F. Supp. 776 (E.D. Pa.), appeal dismissed, 364 U.S. 518 (1960); United States v. Loew's, Inc., 20 F.R.D. 423 (S.D.N.Y. 1957) ; United States v. Loew's, Inc., 136 F. Supp. 13 (S.D.N.Y. 1955); United States v Bearing Distributors Co., 18 F.R.D. 228 (W.D. Mo. 1955); United States v. American Soc'y of Composers, Authors \& Publishers, 11 F.R.D. 511 (S.D.N.Y. 1951); Umited States v. General Elec. Co., 95 F. Supp. 165 (D.N.J. 1950).

Petitions to intervene lave been allowed where expressly permitted by the consent decree provisions: Missouri-Kansas Pipe Lime Co. v. United States, 312 U.S. 502 (1941); United States v. Vehicular Parking, Ltd. 7 F.R.D. 336 (D. Del. 1947); where the decree provisions were prejudicial to a property right: United States v. California Co-op. Canneries, 279 U.S. 553 (1929) (dictum); United States v. Terminal R.R. Ass'n, 236 U.S. 194 (1915); where the question was ancillary to the antitrust proceeding: Olympic Ref. Co. v. Carter, 332 F.2d 260, (9th Cir.) cert. denied, 379 U.S. 900 (1964); and where the third party had considerable interest in supporting the consent decree as entered: Umited States v. Swift \& Co., 286 U.S. 106 (1932). No cases were found wherein a petitioner was allowed to intervene prior to the formulation of the consent decree.

45 See GoldBerg 68-69; HoUSe Report 25.

46 See cases cited note 44 supra; cf. Umited States v. American Soc'y of Composers, Authors \& Pubs. 341 F.2d 1003 (2d Cir. 1965).

47 E.g., Allen Calculators, Inc. v. National Cash Register Co., 322 U.S. 137 (1944).

48 E.g., United States v. Loew's, Inc., 20 F.R.D. 423 (S.D.N.Y. 1957). The only cases found where petitions to intervene were granted over the Government's opposition were Missouri-Kansas Pipe Line Co. v. United States, 312 U.S. 502 (1941), and United States v. Terminal R.R. Ass'n, 236 U.S. 194 (1915).

49 United States v. American Soc'y of Composers, Authors \& Pubs., 11 F.R.D. 511, 513 (S.D.N.Y. 1951).

50 Ibid. 
The Justice Department has not favored third party participation in consent decree negotiations. The complications inherent in intervention plus the unwillingness of defendants to negotiate in the presence of third parties $^{51}$ have contributed to the current practice of secret negotiations. Moreover, government compromise on certain demands for injunctive relief might seem unnecessary to intervening parties. Where the third party is a state, such compromise could result in political pressure and criticism. $^{.2}$

The practice of negotiating in secret-despite its apparent necessityhas provoked extensive criticism of the consent decree program. Critics have charged that secret negotiations reduce judicial control over antitrust actions, provide no record for future guidance of the courts or bar in similar situations, may adversely affect third party interests, and increase both the ease with which the public interest can be compromised and the possibility of exacting from a defendant relief in excess of that likely to be granted by a court. ${ }^{53}$

The Justice Department, probably to allay some of this criticism, has instituted the policy of filing proposed consent decrees with the court thirty days before entry..$^{54}$ Interested third parties are provided the opportunity to review the decree provisions and to make known their criticisms, either to the court or to the Justice Department. This policy has had no siguificant effect on consent decree negotiations nor has it disrupted the administration of the consent decree program. Perhaps there is little need for such a procedure..$^{55}$ In any event, it does serve as a prophylactic to potentially harmful consent decrees, and as such, is of value. ${ }^{56}$

51 See GoLDBERg 68-69.

02 See McHenry, The Asphalt Clause-A Trap for the Unwary, 36 N.Y.U.L. Rev. 1114, 1119-20 (1961).

53 See House Report, 25-26, 304; Goldberg 68-69; see also Stedman, The Committee's Report: More Antitrust Enforcement-Or Less?, 50 Nw. U.L. Rev, 316, 324 (1955).

5426 Fed. Reg. 6026 (1961).

55 See Loevinger, Antitrust in 1961 and 1962, 8 Antitrust BuLl. 349, 352-53 (1963).

56 A regulation promulgated by the European Economic Commission provides interested third parties an opportunity to be heard when the Commission is considering an application under Articles 85(3) to exempt certain business arrangements from the Common Market antitrust provisions. Articles 19, $\$ 2$ of Reg. No. 17, 5 Journar OfFicrer des Comarunautes Europeenes 204 (Feb. 21, 1962), translated in CCH, Cowaron Mxt. Rep. I 2581. Another regulation provides for publication of Commission decisions on applications for antitrust exemptions. Third parties are invited to present their views on the decision within a specified time limit. Article 19, $\S 3$ of Reg. No. 17, 5 Journar Officter des Comamunautes Europeenes 204 (Feb. 21, 1962) translated in CCH Comaron MKT. REp. If 2581. This regulation is comparable to the Justice Department's policy of filing consent decrees with the court thirty days before entry. See text accompanying note 54 supra. 
II

ATTEMPTS TO PRESERVE PRIVATE ACTIONS

\section{A. An Admission in the Decree: The Asphalt Clause}

Attempts have been made to circumvent the section 5 (a) proviso so as to permit both the entry of a consent decree and the use of a government judgment as prima facie evidence in treble damage actions. In three actions in Massachusetts, the Government successfully used a consent decree provision known as the "asphalt clause" wherein the defendants admitted violating the antitrust laws. ${ }^{57}$ The admission was expressly limited to allow use of the judgment as prima facie evidence only in actions by states or their political subdivisions instituted prior to the entry of the consent decree. ${ }^{.8}$

United States v. Brunswick-Balke-Collender Co. ${ }^{50}$ appears to be the only case other than the Massachusetts cases in which the clause was involved. In Brunswick, the parties had agreed upon injunctive relief. The Government, however, conditioned its consent upon inclusion of the "asphalt clause" in the decree. The defendants, refusing to accede to this demand, moved for entry of the decree with only the agreed upon injunctive relief included. The court granted the motion, reasoning that section 5(a) of the Clayton Act gives a defendant the unqualified riglit to a consent decree where all necessary injunctive relief is provided; the Justice Department can not deny that right. ${ }^{60}$ The court believed that the primary purpose of section 5(a) is to induce defendants to enter into consent decrees rather than to encourage and aid private litigants in treble damage actions.

The Supreme Court, in United States v. Ward Baking, expressly reserved decision on the propriety of the asplialt clause. Neither the language nor the legislative history of the Clayton Act provide a conclusive answer on the issue; both support for ${ }^{61}$ and criticism ${ }^{62}$ of the Bruns-

57 United States v. Allied Chem. Corp., 1961 Trade Cas. 77,641 (D. Mass. 1960); United States v. Bituminous Concrete Ass'n, Inc., 1960 Trade Cas. 77,486 (D. Mass. 1960); United States v. Lake Asphalt \& Petroleum Co., 1960 Trade Cas. 77,271 (D. Mass. 1960). 58 This limitation was pursuant to Justice Department policy. See $2 \mathrm{CCH}$, Trade REG. REP. If 8811.72 , at $14,291-92$. It is questionable whether the restriction is warranted. Permitting non-state litigants to use the asphalt clause might provide a greater deterrent to similar future practices.

59203 F. Supp. 657 (E.D. Wis. 1962).

$60 I d$. at 662 .

61 See McHenry, The Asphalt Clause-A Trap for the Unwary, 36 N.Y.U.L. Rev. 1114, 1122 (1961); Dabney, Consent Decrees Without Consent, 63 Colun L. REv. 1053, 1062-63 (1963). The decision in Brunswick was based on the legislative history of $\S 5(a) .203$ F. Supp. at 661-62.

62 See Comment, 1963 WIs. L. Rev. 459. See also United States v. Standard Ultramarine \& Color Co., 137 F. Supp. 167, 171-72 (S.D.N.Y. 1955). 
wick result have been rationalized by reference to the Act's history. Implicit in Ward Baking, however, is the notion that the Attorney General has the discretionary power to effectively force a trial where the Government insists upon injunctive relief beyond that which the defendant will accept. If, in this manner, the Attorney General can force a trial which will result in a section 5(a) judgment, there would seem to be little reason why the asphalt clause should not be used to provide a section 5(a) judgment.

Further, it seems more realistic to allow the Justice Department to determine whether the public interest is better served by such an admission. The Department, in consent decree negotiations, is in a position analogous to a regulatory agency; it presumably knows the history of the defendant's activities and, therefore, is more competent than a court to determine the effects of the alleged violations on competitors and other third parties. A defendant always has the alternative of litigation when the Government insists upon the asplialt clause as a condition for a consent decree. Litigation would shift the responsibility of providing adequate relief to the court. But to bar the Justice Department from insisting on such an admission in consent decree negotiations is to hold that a determination of what is best in the public interest does not involve consideration of potential treble damage litigants. It seems unlikely that government assistance to state actions by use of the asphalt clause would most often be inconsistent with the public interest. Where only private interests are affected, an admission could help accelerate restoration of competitive conditions if the Government chose to extend the clause's utility beyond state actions. ${ }^{63}$

The infrequent use of the asphalt clause evidences its impracticality. The obvious reason for the clause's limited utility is that few defendants will accept it. Presumably the clause is useful only where there are potential treble damage litigants, yet in that situation the defendant has little to lose by taking his chances at trial. ${ }^{64}$ Only when the Government's case is so strong that the defendant lias nothing to gain by litigation will

03 Proposed H.R. Res. 3787, 88th Cong. 1st Sess. would have amended $\$ 4$ of the Clayton Act by adding: "Each such [treble damage action] suit shall be deemed to be impressed with a substantial public interest." The primary purpose of the bill may have been to enable the courts to declare contract provisions holding one party harmless for possible antitrust violations contrary to public policy and void. See S. REP. No. 1855, 85th Cong., 2d Sess. 8 (1958). Such an amendment, however, would have lent support to the argument that the Justice Department may seek, through an admission or an adjudication, a judgment available as prima facie evidence.

64 A defendant's decision is more complicated where third parties other than state governments stand to benefit by a $\S 5$ (a) judgment. In addition to considering the probable extent of damages under the alternatives of trial or admission, the defendant must estimate his chance of success in the event of trial. 
the clause be of use. ${ }^{65}$ Another reason for the clause's infrequent use may be judicial hostility, apparent in Brunswick. One might expect trial courts to disapprove introduction of the clause into consent decree negotiations; the judicial problems inherent in trying an antitrust case, ${ }^{60}$ the pressures of congested calendars, ${ }^{67}$ and the skepticism of some judges about the value of antitrust litigation ${ }^{88}$ would tend to make the clause unpopular, particularly where it is a primary factor forcing a suit to litigation. ${ }^{69}$ Political considerations could also be a factor tending to discourage use of the clause.

Despite these problems, the Government has not abandoned the asplalt clause. The Justice Department in its brief for Ward Baking claimed the discretionary power to insist upon the clause or force an adjudication where one of those alternatives is believed necessary for effective relief $;^{70}$ whether the Department has that power was not decided by the Court. Even if the Department's contention is correct, the clause's inherent difficulties prolibit its extensive use. The antitrust division cannot litigate a large number of suits due to limited manpower and financial resources together with an ever increasing number of complaints to be investigated. ${ }^{71}$ Insistence on the clause is likely to force a trial; thus its utility will be limited by the division's abilities to litigate.

\section{B. Criminal Judgments: Quasi-Consent Decrees}

Successful criminal prosecutions under the antitrust laws ${ }^{72}$ may aid third parties in subsequent treble damage hitigation. A conviction after

65 The Government might also be in a position to use the asphalt clause as an in terrorem device to extract more injunctive relief in a jurisdiction that does not follow Brunswick.

68 See McAllister, The Big Case: Procedural Problems in Antitrust Litigation, 64 Hanv.

L. Rev. 27 (1950).

67 See Acheson, Professional Responsibility and the Workload of the Federal District Courts, 52 GEo. L.J. 542, 545-46 (1964). Acheson's computations, based on Director of the Administrative Office of the US. Courts Ann. Rep. (1963), showed the median interval from joinder of issue to trial in various districts to be: Southern New York, 34 months; Eastern Pennsylvania, 37 months; Northern Illinois, 15 months; Northern Cahifornia, 17 months; Southern California, 11 months.

68 Hardy, The Evisceration of Section 5 of the Clayton Act, 49 Gro. L. J. 44, 68-69 (1960).

68 This was the situation in Brunswick. However, as was suggested in Comment, 1963 Wrs. L. REv. 459, 468, recurrence of the Brunswick situation is unlikely. The Government, especially after United States v. Ward Baking, 376 U.S. 327 (1964), is likely to demand more injunctive relief than the defendant is willing to grant rather than admit that the asphalt clause is the sole factor in dispute. See also Dabney, Consent Decrees Without Consent, 63 Colus. L. Rev. 1053, 1063 (1963).

70 Brief for Appellant, p. 12, United States v. Ward Baking Co., supra note 69.

71 See note 28 supra.

72 Several antitrust laws provide criminal penalties, e.g., Sherman Act $\S 1,69$ Stat. 282 (1955), 15 U.S.C. \& 1 (1958). 
trial is available as prima facie evidence to private litigants. ${ }^{73}$ The decisions conflict on the question whether conviction on a guilty plea is within the section 5(a) proviso; the trend is to lold that a judgment entered on such a plea is available as prima facie evidence. ${ }^{74} \mathrm{~A}$ judgment entered upon a plea of nolo contendere, however, is considered a consent decree and is of no aid to private litigants. ${ }^{75}$

The trial judge has discretion to accept or reject a plea of nolo contendere. $^{76}$ The Justice Department's general policy to oppose nolo contendere pleas $^{77}$ has not been particularly successful; ${ }^{78}$ courts liave often accepted the plea over the Government's attempt to force a guilty plea or trial. ${ }^{7 \theta}$ Where the Government has been able to convince the court

73 Emich Motors Corp. v. General Motors Corp., 340 U.S. 558 (1951).

$74 \mathrm{~A}$ guilty plea is a consent judgment, therefore not within the proviso: Northwest Elec. Power Co-op. v. General Elec. Co., 30 F.R.D. 557 (W.D. Mo. 1961); Barnsdall Ref. Corp. v. Birnamwood Oil Co., 32 F. Supp. 308 (ED. Wis. 1940) (dictum); Twin Ports Oil Co. v. Pure Oil Co., 26 F. Supp. 366 (D. Minn. 1939) (dictum), af'd, 119 F.2d 747 (8th Cir.) cert. denied, 314 U.S. 644 (1941). Guilty plea is not a consent judgment: General Elec. Co. v. City of San Antonio, 334 F.2d 480 (5th Cir. 1964); City of Burbank v. General Elec. Co., 329 F.2d 825 (9th Cir. 1964); Commonwealth Edison Co. v. AllisChalmers Mfg. Co., 323 F.2d 412 (7th Cir. 1963); Atlantic City Elec. Co. v. General Elec. Co., 207 F. Supp. 620 (S.D.N.Y. 1962).

The latter view seems preferable. Where both the court and the Justice Department believe a $\$ 5$ (a) judgment is in the public interest, it seems desirable to accomplish such an end without having to force the issue to litigation. The court, if it believes such a judgment is not needed, may accept a defendant's plea of nolo contendere. See Matteoni, Antitrust Ambiguity Under Section 5(a) of the Clayton Act, 11 U.C.L.A.L.REv. 792 (1964).

75 City of Burbank v. General Elec. Co., supra note 74. "The split of authority on [whether a guilty plea is a consent judgment] ... . is almost as marked as is the unanimity of opmion with respect to the holding that nolo contendere pleas come within the proviso of $\S 5$ (a) [of the Clayton Act]." Id. at 834.

"[T]he only basic characteristic of the plea of nolo contendere which differentiates it from a guilty plea is that the defendant is not estopped from denying the facts to which he pleaded nolo contendere in a subsequent judicial civil proceeding." Lenvin \& Meyers, Nolo Contendere: Its Nature and Implications, 51 YALE L.J. 1255, 1263 (1942).

78 Rule 11 of the Federal Rules of Criminal Procedure provides: "A defendant may plead not guilty, guilty or, with the consent of the court, nolo contendere ...."

$7 \tau$ Letter from Mr. William H. Orrick, Jr., Assistant Attorney General in charge of the antitrust division, to the California Law Review, Nov. 9, 1964, on file in the office of the California Law Review.

78 The Court in United States v. Minneapolis-Honeywell Regulator Co., 1963 Trade Cas. 78,494, 78,495 (D. Minn. 1963), noted that from 1955 to 1963 trial courts had accepted 104 out of 142 nolo pleas despite Justice Department opposition. For a thorough discussion of considerations relevant to accepting or rejecting such a plea, see United States v. Standard Ultramarine \& Color Co., 137 F. Supp. 167 (S.D.N.Y. 1955).

79 In United States v. Safeway Stores, 20 F.R.D. 451 (N.D. Tex. 1957), the court rejected the Government's arguments in opposition to a nolo plea, saying, "[T]he Government's responsibility in bringing cases of this nature is to vindicate the public interest in preserving a competitive economy rather than to redress private wrongs and recover damages for injuries ssutained by individuals.' " Id. at 456 . 
that the public interest demands a judgment of guilty because of aggravated circumstances, the courts have rejected the nolo plea. ${ }^{80}$ Some opinions have suggested, however, that the plea will be rejected only where such aggravated circumstances exist. ${ }^{81}$

The Justice Department is not precluded from prosecuting concurrent criminal and civil antitrust actions based upon the same factual allegations..$^{82}$ Consequently, if the Department concludes that the court's acceptance of a nolo contendere plea is inconsistent with the public interest, it may seek injunctive relief and an adjudication of an antitrust violation through a civil proceeding.

Legislation has been proposed whicl would make nolo contendere pleas accepted over the Government's objection admissible as prima facie evidence in treble damage actions. ${ }^{83}$ It seems likely that enactment of such a proposal niight encourage defendants to proceed to trial where the Government opposes a nolo plea: trial offers some chance of acquittal. Should increased litigation result, the Government, because of a limited capacity to litigate, would probably be forced to be more selective in opposing nolo pleas. In any event, it is possible that such litigation would result in making more criminal judgments available as prima facie evidence to private litigants.

\section{Tolling the Statute of Limitations}

Section 5(b) of the Clayton Act provides that the statutory limitations period barring private actions is tolled by the Government's commencing a suit under the antitrust laws. ${ }^{84}$ Early filing of the government

80 See United States v. Westinghouse Elec. Corp., 1960 Trade Cas. 76,753 (E.D. Pa. 1960).

81 See United States v. Minneapolis-Honeywell Regulator Co., 1963 Trade Cas. 78,494 (D. Minn. 1963) ; United States v. B. F. Goodrich Co., 1957 Trade Cas. 72,871 (D. Col. 1957). But see United States v. Engelhard-Hanovia, Inc., 1964 Trade Cas. 79,161 (S.D.N.Y. 1964); United States v. Pittsburgh Plate Glass Co., 1957 Trade Cas. 73,327 (W.D. Va. 1957).

82 United States v. National Ass'n of Real Estate Bds., 339 U.S. 485 (1950) (defendants' acquittal in prior criminal action does not bar civil proceeding on same issues).

${ }^{83}$ H.R. 8253, 88th Cong., 1st Sess. (1963). The proposed bill also would have provided that judgments entered on pleas of guilty would not be considered consent judgments. See note 74 supra and accompanying text.

84 "Whenever any civil or criminal proceeding is instituted by the United States to prevent, restrain, or punish violations of any of the antitrust laws ... the running of the statute of limitations in respect of every private right of action arising under said laws and based in whole or in part on any matter complained of in said proceeding shall be suspended during the pendency thereof and for one year thereafter: Provided, however, That whenever the running of the statute of himitations in respect of a cause of action arising under section 15 of this title is suspended hereunder, any action to enforce such cause of action shall be forever barred unless comnenced either within the period of 
complaint may preserve a third party's claim against the defendant. ${ }^{85}$ Moreover, section $5(\mathrm{~b})$ facilitates a private action by permitting the party to await the final outcome in the government proceeding, ${ }^{88}$ which if successful may provide a judgment available as prima facie evidence.

The Government may also help to preserve a third party's claim by carefully drafting its complaints. ${ }^{87}$ A private plaintiff receives the benefit of section 5(b) only if the treble damage action is "based in whole or in part on any matter complained of in the government proceeding." Some courts have narrowly construed this provision: "Tlie same means must be used to achieve the same objectives of the same conspiracies by the saine defendants." 88 Thus, a private action against wholly owned subsidiaries involved in a conspiracy with the parent corporation for which only the parent corporation was prosecuted by the Government was not preserved by section $5(\mathrm{~b}){ }^{89}$ The Governinent could forestall similar results by comprehensive complaint allegations.

\section{III}

PROSPECTS FOR THE FUTURE: CONTEMPT JUDGMENTS

\section{AND GOVERNMENT DISCOVERY}

Third party use of government procured contempt judgments-as prima facie evidence of an antitrust violation-and of results from government action discovery are both recent developments. Whether these means will be of significance to future private litigants probably will

suspension or within four years after the cause of action accrued. Clayton Act $\S 5(\mathrm{~b})$, as amended 69 Stat. 283, 15 U.S.C. \& 16(b) (1958).

85 In this respect, the antitrust division's former practice of negotiating with a defendant for a consent decree prior to filing the complaint was detrimental to potential private litigants. A private claim could have been barred by the time a complaint was filed. In the event of unsuccessful negotiations and the entry of a $\$ 5(a)$, judgment, a potential recovery by the third party would have been defeated by the pre-filing negotiations. See text accompanying note 133 infra.

${ }^{86}$ Charles Rubenstein, Inc. v. Columbia Pictures Corp., 154 F. Supp. 216 (D. Minn. 1957).

87 See Spivack, Antitrust Enforcement in the United States: A Primer, 37 Cons. B.J. 375 (1963). See generally Freund, The Pleading and Pre-Trial of an Antitrust Claim, 46 CORNELL L.Q. 555 (1961).

88 Steiner v. 20th Century-Fox Film Corp., 232 F.2d 190, 196 (9th Cir. 1956). See Leh v. General Petroleum Corp., 208 F. Supp. 289 (S.D. Cal. 1962), aff'd, 330 F.2d 288, cert. granted, 379 U.S. 877 (1964). But see 20th Century Fox Film Corp. v. Goldwyn, 328 F.2d 190 (9th Cir.), cert. denied, 379 U.S. 880 (1964); Radio Corp. of America v. Rowland Corp., 186 F. Supp. 704 (N.D. Ill. 1956).

${ }^{80}$ Sun Theatre Corp. v. RKO Radio Pictures, Inc., 213 F.2d 284 (7th Cir. 1954); Court Degraw Theatre, Inc. v. Loew's, Inc., 172 F. Supp. 198 (E.D.N.Y. 1959); cf. Skouras Theatres Corp. v. Radio-Keith-Orpheum Corp., 193 F. Supp. 401 (S.D.N.Y. 1961). But cf. Union Carbide v. Nisley, 300 F.2d 561 (10th Cir. 1961), cert. denied, 371 U.S. 801 (1962). 
depend on whether the Government believes the consent decree program will be adversely affected.

\section{A. Contempt Judgments: The Means to Effective Decree Enforcement}

Contravention of a consent decree ${ }^{80}$ may subject the defendant to contempt proceedings. ${ }^{91}$ Whether a judgment of conviction in a contempt proceeding is available as prima facie evidence was considered in Simco Sales Service, Inc. v. Air Reduction Co. ${ }^{92}$ The defendant in Simco contended that the judgment was not available for that purpose because of two infirmities. First, a contempt judgment determines only that the defendant has violated the consent decree provisions; there has been no judicial determination that the conduct violated the antitrust laws. Second, the Clayton Act's defimition of the "antitrust laws" does not include contempt proceedings brought to enforce consent decrees; $;^{03}$ therefore, a contempt prosecution fails to meet the requirement of section 5(a) that it be a proceeding brought "under the antitrust laws."

The court, disposing of the defendant's second point, distinguished contempt proceedings brought to vindicate the court's power. It held that a proceeding brought by the Government to enforce compliance with a consent decree intended to enforce the antitrust laws was ancillary to, and therefore under, those laws. ${ }^{94}$ The court recognized, however, that the conduct for which the defendant was held in contempt may not have

${ }^{80} \mathrm{~A}$ private litigant generally may not allege that a defendant has violated a government procured consent decree. Paul M. Harrod Co. v. A. B. Dick Co., 194 F. Supp. 502 (N.D. Ohio 1961); Kearuth Theatres Corp. v. Paramount Pictures, Inc., 1956 Trade Cas. 72,309 (S.D.N.Y. 1956). There are two reasons for striking the allegation that a defendant las violated a government procured consent decree. First, the private action granted by $\$ 4$ of the Clayton Act lies only for a violation of the antitrust laws. Consent decrees might enjoin acts both legal and illegal under these laws. See United States v. United States Gypsum Co., 340 U.S. 76, 88-89 (1950). An act contrary to the provisions of a consent decree, therefore, may not be illegal under the antitrust laws. Second, consent decrees typically provide that there has been no adjudication of an antitrust violation. Because a treble damage action must be based upon such a violation, the allegation that an act contravenes a consent decree does not state a claim for relief. See United States v. American Soc'y of Composers, Authors \& Publishers, 341 F.2d 1003 (2d Cir. 1965).

01 "A court of the United States shall lave power to punish by fine or imprisonment, at its discretion, such contenipt of its authority, and none other, as ...

(3) Disobedience or resistance to its lawful writ, process, order, rule, decree, or command."

62 Stat. 701 (1948), 18 U.S.C. $\$ 401$ (1958).

82213 F. Supp. 505 (E.D. Pa. 1963).

${ }^{93}$ See Nashville Millk Co. v. Carnation Co., 355 U.S. 373 (1958).

94 Inasmuch as the Clayton Act definition of the antitrust laws does not include the statute recognizing the federal courts' contempt power, it could be argued that a contempt judgment is not within $\S 5$ (a) of the Clayton Act. If, lowever, the purpose of the contempt proceeding is to effectuate a consent decree, it would seem unwise to limit the deterrents to decree violations by so narrow a construction of the ancillary concept. 
violated the law; further evidence pertaining to the contempt judgment and the consent decree would have to be introduced before ruling on the judgment's admissibility.

Simco suggests that the benefit a private hitigant will derive from a contempt judgment depends on two factual determinations: the particular practices enjoined in the consent decree and the conduct for which the contempt judgment was entered. If the contemptuous conduct is per se a violation of the antitrust laws, the contempt judgment as prima facie evidence would substantially aid a private party. If, however, the conduct was not per se a violation, further inquiry is necessary. The first question is whether the conduct found contemptuous was legal at the time it was enjoined in the consent decree. If it was, the private plaintiff would derive no benefit from the contempt judgment other than its probative value on the issue of commission of the act; there would remain the burden of proving the conduct now constitutes a violation of the law.

If, under the rule of reason doctrine, ${ }^{95}$ the contemptuous conduct may or may not have been legal at the time it was enjoined, the court must decide whether commission of the prohibited conduct justifies allowing the introduction of the contempt judgment as a section 5(a) judgment. Consent decrees typically make no provision on the issue of an antitrust violation. A conviction of contempt determines only that the defendant committed an act enjoined in the decree; it does not adjudicate the issue of whether the act was illegal.

A court might, however, allow introduction of the contempt judgment as prima facie evidence of a violation in the belief that such a policy would proinote compliance with antitrust decrees. This procedure does not seen unfair. The defendant is best able to show why the conduct in question should not be considered illegal; all the economic factors which compelled him to commit the acts are at his command. ${ }^{96}$

If the courts are reluctant to allow the contempt judgment as priuna facie evidence-principally because of its possible prejudicial effect on a jury ${ }^{97}$ - other means of making the contempt judgment of greater use to private hitigants could be utilized. The courts conceivably could

95 The "rule of reason" requires an extensive exploration of facts to determine whether the economic effects of the conduct in question make it illegal. Conduct which requires only a determination that the act was committed is a "per se" violation of the law. Whether the "rule of reason" characterizes a standard by which an act may be "reasonably anticompetitive," and therefore legal, or refers to a methodology used in determining whether an act is anti-competitive, and therefore illegal, is an open question. See Loevinger, The Rule of Reason in Antitrust Law, 50 VA. L. REv. 23, 23-25, 33-34 (1964).

96 See Cleary, Presuming and Pleading: An Essay on Juristic Immaturity, 12 StaN. L. REv. 5, 8-14 (1959).

97 See note 102 infra. 
charge a defendant convicted of contempt with the burden proving its conduct consistent with the antitrust laws. ${ }^{08}$ The Justice Department might be able to accomplisl the same result through a stipulation in the consent decrees. ${ }^{99}$ For several reasons, such a provision miglit not encounter the judicial lostility suffered by the asplialt clause in United States v. Brunswick-Balke-Collender Co. ${ }^{100}$ First, the provision would be operative only for future conduct; it would not affect the defendant's vulnerability to treble damage actions for conduct prior to entry of the decree. Second, it would seem desirable to limit to past conduct the insulation from treble damage actions afforded by a consent decree. The likelihood of treble damage judgments is believed to be a major deterrent to possible antitrust violations. ${ }^{101}$ Private actions most often follow a successful government litigation. Yet, where a defendant's conduct contravenes a consent decree, the Governinent is unlikely to institute a de novo antitrust action rather than a contempt proceeding. Therefore, encouraging the prophylactic effect of potential treble damage actions would probably have to be achieved through a reallocation of the burden of proof. Though the primary reason for enacting section 5(a) of the Clayton Act may have been to encourage consent decrees, it seems unlikely that Congress intended to extend the protection afforded by such a decree to acts committed after entry of the decree. Third, unlike the effect of an admission, a stipulation shifting the burden of proof would not deprive the defendant of his day in court on the issue whether the conduct in question is illegal. ${ }^{102}$

98 Placing the risk of non-persuasion upon the party found guilty of violating a consent decree is consistent with the policy of granting private parties the right to recover for injuries suffered because of antitrust violations. The objectives of providing a riglit to relief are to maintain a competitive economy as well as to redress injuries to private parties. See Lawlor v. National Screen Serv. Corp., 349 U.S. 322, 329 (1955); Mach-Tronics, Inc. v. Zirpoli, 316 F.2d 820, 828 (9th Cir. 1963). See generally MacIntyre, The Role of the Private Litigant in Antitrust Enforcement, 7 ANTimost BuxL. 113 (1962); Loevinger, Private Action-The Strongest Pillar of Antitrust, 3 ANrrrrost BuLl. 167 (1958). Thougli consent decrees may enjoin acts that are in themselves legal, the practice enjoined must lave been one whose continued existence was believed by either the court or the Justice Department to be contrary to the public interest. It does not seem unfair, therefore, to place upon the defendant the burden of showing that the violative acts were consistent with the policies of the antitrust laws. See generally Cleary, Presuming and Pleading: An Essay on Juristic Immaturity, 12 StAN. L. REv. 5, 8-14 (1959).

99 Analogous are the modifieation clauses allowing the Government to apply for further injunctive relief after a certain number of years. In Umited States v. National Cranberry Ass'n, 1957 Trade Cas. 73,443 (D. Mass. 1957), the consent decree provided that upon application by the Government for further relief, the defendants would lave to assume the burden of showing why the requested relief should not be granted.

100203 F. Supp. 657 (E.D. Wis. 1962).

101 See MacIntyre, supra note 98; Loevinger, supra note 98.

102 Though the asphalt clause is meant to have only a prima facie effect, an admission 
It has been suggested that Congress enact legislation allowing private litigants to recover for injuries resulting from conduct which contravenes a government consent decree. ${ }^{103} \mathrm{~A}$ prior government contempt proceeding would, under this proposal, be unnecessary. The plaintiff would have to prove only that the acts occurred and that they violated the consent decree; there would be no necessity of proving the acts illegal. The legislation, as a means of further assistance to private litigants, could provide that a contempt judgment based on a consent decree would be prima facie evidence of a violation in a private action. ${ }^{104}$

Such legislation, in addition to the assistance it would furnish private litigants, might give the Justice Department an effective ally in its enforcement program. If, as has been charged, there is a lack of subsequent enforcement of antitrust decrees, ${ }^{105}$ legislation could help correct that deficiency. A private plaintiff presumably would be less hesitant to bring an action in which it would be necessary to prove only that conduct prohibited by a consent decree had occurred and had caused injury; the complex arguments inherent in the issue of an antitrust violation would not be present. It could be expected, therefore, that the private sector of the antitrust enforcement mechanism would be more active than it has been heretofore. ${ }^{108}$

\section{B. Third Party Use of Government Action Discovery}

A private litigant might derive benefit from a government prosecuted action, notwithstanding the entry of a consent decree. Third party utilization of the fruits of discovery from a prior government proceeding was made possible recently by Olympic Refining Co. v. Carter ${ }^{107}$ In preparation for a treble damage action against Standard Oil of California and General Petroleum Corporation, Olympic refining served a subpoena duces tecum on an officer of the Justice Department. The officer was

incorporated into a decree is more likely to have a conclusive effect, especially when the trier of fact is a jury. See Seeley, The Pitfalls Which Lurk in Government Litigation for Defendants Who May Be Subjected to Treble Damage Actions, 4 Antrtrust BuLc. 17, 20 (1959).

103 The author is indebted to Maxwell M. Blecher, Esq., of the San Francisco Bar for this suggestion.

104 Enactment of legislation incorporating these proposals would, of course, render moot the textual discussion regarding Simco Sales Serv., Inc. v. Air Reduction Co., 213 F. Supp. 505 (E.D. Pa. 1963). See text accompanying note 92 supra.

105 See, e.g., GoLdBerg 66; Phillips, The Consent Decree in Antitrust Enforcement, 18 Wash. \& Lee L. Rev. 39, 50-51 (1961); House Report 16.

108 The remedy provided by the suggested legislation might be less than treble damages. That would depend on the effects the act probably would have on the consent decree program. The act could provide for assessment of multiple damages only for certain practices, either automatically or in the court's discretion.

107332 F.2d 260 (9th Cer.), cert. denied, 379 U.S. 900 (1964). 
required to produce copies of certain documents involved in the pre-trial discovery of a previous Government proceeding against the saine defendants; ${ }^{108}$ those proceedings had been terminated by a consent decree. ${ }^{109}$ The documents, on file in another district court, were under three protective orders entered several years earlier prohibiting their disclosure. To comply with the subpoena, the Government and Olympic moved, over the defendants' objections, to vacate the protective orders, alleging the lack of need for further protection of information once considered competitively sensitive. The trial court denied the motion, not because of any need for continued protection, but because of the belief that the orders had expedited procurement of a consent decree by inducing a fuller disclosure by the defendants than might otherwise have been required.110 In the trial court's view, there had been a quid pro quo-full disclosure in exchange for a protective order.

Reversing, the Court of Appeals held that neither Rule $30(\mathrm{~b})$ of the Federal Rules of Civil Procedure-pursuant to which the protective orders had been entered-nor section 5(a) of the Clayton Act provided the broad protection the District Court's decision implied. ${ }^{111}$ Information otherwise available to the public or at least to other litigants cannot be held under seal indefinitely. The court, concluding that congressional policy favors public proceedings in antitrust actions, held that the plaintiff was "entitled to have the orders reconsidered .... and modified in such form as to permit access to the docunents subject to reasonable restrictions as to disclosure ...."112 That Olympic could have obtained the same data through its own discovery was considered irrelevant.

The Olympic Refining court ${ }^{113}$ analogized from the policy it found

108 The documents required by the subpoena duces tecum were: (1) the Government's answers to the defendant's interrogatories; (2) documents describing the documentary materials and oral testimony, and the statements of witnesses to be used by the Government at trial; (3) an outline of the Government's contentions.

109 United States v. Standard Oil Co., 1959 Trade Cas. 75,522 (S.D. Cal. 1959). For further discussion of this case, see text accompanying note 22 supra.

$110 \mathrm{By}$ agreement, the defendants had been allowed to apply to the court for the protective orders before the documents became a matter of public record.

111332 F.2d at 265 .

112 Id. at $265-66$.

113 Before reaching the discovery issue, the court of appeals disposed of the defendant's contention that an appeal for the trial court's order could be taken only to the Supreme Court. Appeals from final or interlocutory orders in Government civil antitrust suits generally must be taken directly to the Supreme Court, pursuant to the Expediting Act, 62 Stat. 989 (1948), 15 U.S.C. \& 29 (1958). The court, however, held that the order in question was ancillary to the Government's main action and therefore reviewable by the court of appeals. 332 F.2d at 263. Cf. Shenandoah Valley Broadcasting, Inc. v. American Soc'y of Composers, Authors \& Publishers, 375 U.S. 39 (1963), modified, 375 U.S. 994 (1964). 
reflected by the Publicity in Taking Evidence Act. ${ }^{114}$ The Act provides for public proceedings where depositions are taken for use in a Government antitrust action. Enacted in 1913, the Act was a reaction to an order in a government antitrust action directing testimony before a master to be taken behind closed doors. ${ }^{115}$ Congress gave two reasons for its enactment. First, public proceedimgs often caused third parties to bring to the Attorney General's attention evidence that would not otherwise have been obtained. ${ }^{116}$ Second, closed door proceedings are inconsistent with the American manner of conducting trials. ${ }^{117}$ The objections urged against the bill seem apposite to the defendant's situation in Olympic Refining. The hearings covered by the Act provide for little more than taking depositions. Although an attorney may object that a question is immaterial, the witness is bound to answer. Only subsequently does a court rule on the objection. This allows a shrewd attorney to extract trade secrets to the detriment of the concern. ${ }^{118}$ Despite these potential abuses, the bill was passed. ${ }^{119}$

The Olympic Refining defendants, in their unsuccessful petition to the Supreme Court for a writ of certiorari, argued for a narrow construction of the Act; they urged that its application should be himited to hearings at which testimony is to be taken only for use at trial and not extended to discovery procedures where extraneous information may be presented. ${ }^{120}$ Two kinds of hearings are mentioned in the Act. The first, "the taking of depositions of any witnesses for use in any suit in equity brought by the United States," could be construed to mclude hearings involving only the taking of depositions to be introduced as evidence at trial. The statute goes on, however, to provide for "hearings before any examiner or special master appointed to take testimony." The defendant's construction seems to encompass only these latter hearings before an examiner or master. The legislative history is inconclusive:

11437 Stat. 731 (1913), 15 U.S.C. $\$ 30$ (1958).

115 See United States v. United Shoe Mach. Co., 198 Fed. 870 (D. Mass. 1912).

11649 Conc. REC. 2512, 2513 (1913). "If we are going to permit the decision of [United States v. United Shoe Mach. Co.] . . to stand ... you will be met at the threshold of every prosecution under the Sherman Antitrust law with an application for a secret hearing." Id. at 2513. (Remarks of Representative Norris.)

$117 \mathrm{Id}$. at 2513,4627 .

$118 \mathrm{Id}$. at 4622 .

$110 \mathrm{~S}$. 7999, 62d Cong., 2d Sess. (1913), introduced as a companion bill to the one which became the Publicity in Taking Evidence Act, would have given the examiner taking testimony the power to rule on the relevance of a question. The bill went no further than conmittee. 49 Cong. Rec. 1117 (1913). A proposed amendment to the Publicity in Taking Evidence Act, also unsuccessful, would have accomplished the same result. 49 Cong. REC. 4626 (1913).

120 Petition for Writ of Certiorari, Carter v. Olympic Ref. Co., 332 F.2d 260 (9th Cir.), cert. denied, 379 U.S. 900 (1964). 
The fears of those in opposition to the bill ${ }^{121}$ reflect the belief that the Act could be extended beyond such a reading. ${ }^{122}$

There seems to have been only one prior case referring to the Act. ${ }^{123}$ That was an antitrust action wherein the Suprene Court, in dictum, noted that if the Government had used the grand jury as a device to elicit evidence for a civil action, it would be "flouting" the law; ${ }^{124}$ the policy of the Publicity in Taking Evidence Act was to circumscribe in camera proceedings in Sherman Act cases. ${ }^{225}$

It would seem that one of the foremost purposes of discovery-ascertainment of all relevant facts necessary for an effective litigation of the issues ${ }^{126}$-is better achieved by allowing plaintiffs access to the data procured through discovery in the government proceeding than by requiring them to obtain this information through their own efforts. Contrary to the petitioner's claim in Olympic Refining, ${ }^{127}$ the Court of Appeals did not deny the trial court the power to continue needed protective orders. In remanding the case, the court ordered modification to allow Olympic access to the documents subject to reasonable restrictions "as may be necessary and practicable to prevent unnecessary disclosure of any present trade secrets." 128 This qualification would seem to require de novo consideration of the necessity for further protection of the material under seal.

Consent decree negotiations have been criticized because of the

121 See 49 Cong. Rec. 4622 (1913).

122 Another objection urged by the Olympic Refining defendants is the difficulty of reconciling the Act's provision making void any order barring the public from the mentioned hearings to the provision of Rule $30(\mathrm{~b})$ of the Federal Rules. Rule 30 (b) allows the trial court, where cause is shown, to exclude persons other than the parties and their counsel from being present when depositions are taken.

123 United States v. Procter \& Gamble Co. 356 U.S. 677 (1958); Unitcd States v. Procter \& Gamble Co., 180 F. Supp. 195 (D.N.J. 1960).

124356 U.S. at 683.

125 In recommending procedures for expediting the orderly disposition of protracted cases, a judicial conference study group noted that pre-trial protective orders would have to be limited in accordance with the Publicity in Taking Evidence Act. Handbook of Recommended Procedures for the Trial of Protracted Cases, 25 F.R.D. 351, 447 (1960).

126 "The various instruments of discovery now serve (1) as a device, along with the pre-trial hearing ... to narrow and clarify the basic issues between the parties, and (2) as a device for ascertaining the facts, or information as to the existence or whereabouts of facts, relative to those issues." Hickman v. Taylor, 329 U.S. 495, 501 (1947). See 4 MOoRE, Federax Practice If 26.02, at 1031-42 (2d ed. 1953).

127 Petition for Writ of Certiorari, Carter v. Olympic Ref. Co., 332 F.2d 260 (9th Cir.), cert. denied, 379 U.S. 900 (1964). The court of appeals, in remanding, made no mention of the apparent conflict between the Publicity in Taking Evidence Act and Federal Rule 30(b) pertaining to the trial court's power to exclude third parties from discovery proceedings. See note 122 supra.

128332 F.2d at 266. 
secrecy with which they are conducted: ${ }^{129} \mathrm{~A}$ decree may have adverse effects on third parties who have had no opportunity to help formulate or criticize the decree's provisions. Although the Olympic Refining doctrine would not alleviate this specific harm, it might tend to lessen some adverse effects of consent decrees by aiding third parties in subsequent treble damage litigation. To prohibit discovery of data comparable to the documents involved in Olympic Refining would tend to restrict private actions, especially where consent decrees have been entered only after several years of effort. ${ }^{130}$

The major objection to Olympic Refining is that it may adversely affect the Government's consent decree prograin. ${ }^{131}$ Foreseeing the possibility of a situation comparable to that in Olympic Refining, defendants in government antitrust suits may be hesitant about disclosure of potentially harmful information. Moreover, delay may result because of an increase in defendants' objections to Government discovery. ${ }^{132}$ The Government supported the petitioner's motion to vacate the protective orders in Olympic Refining. Nevertheless, the Government may, in order to forestall possible adverse effects on consent decrees negotiations, attempt to circuniscribe Olympic Refining.

Under the current policy of the Justice Department, no consent decree negotiations are conducted with a defendant prior to the filing of a complaint. ${ }^{133}$ Consequently, a defendant who seeks information about the Government's case must wait until the complaint is filed; thereafter, the defendant may obtain factual data and information about the Government's contentions through discovery. Under Olympic Refining, however, this use of discovery could amount to giving a third party a tailormade case-a possible reason for the objections to vacating the protective

120 GoldBerg 68-69; House Reyort 25-26, 304.

130 See Schwartz, The Schwartz Dissent, 1 ANтrtrost BocL. 37, 54 (1955).

131 See BNA, ANTitrust and Trade Regs. Rep. No. 156, at B-5 (July 7, 1964).

132 See generally Speck, The Use of Discovery in United States District Courts, 60 YaLE L.J. 1132, 1150-52 (1951); Comment, Tactical Use and Abuse of Depositions Under Federal Rules, 59 YALE L.J. 117, 131-34 (1949).

133 Letter from William H. Orrick, Jr., Assistant Attorney General in charge of the Antitrust Division, to the California Law Revier, November 9, 1964, on file in the offices of the California Law Review. This is a recent change in policy by the Justice Department. For a discussion of the pre-filing negotiation methods in effect before this policy change, see 5 CCH, Trade Reg. Rep. $\{50,208$, at 55254 (Nov. 12, 1963). The practice of negotiating before filing complaints has been criticized for reducing the few remaining remnants of judicial control over consent decrees. See Schwartz, The Schwartz Dissent, 1 ANTITrost BULL. 37, 54 (1955); Stedman, The Committee's Report: More Antitrust Enforcement or Less, 50 Nw. U.L. Rev. 316, 324 (1955). But see Comment, 55 MICH. I. Rev. 92, 98-99 (1956); Atr'y Gen. Nat'x Comar. Antitrost Rep. 360 (1955). For the detrimental effect of pre-filing negotiations on private litigants, because of the statute of limitations, see note 85 supra. 
orders in Olympic Refining. ${ }^{134}$ Alternatively, the defendant may obtain the information at consent decree negotiations. ${ }^{135}$ Could Olympic Refining be extended to data exchanged at these negotiations? The language of the opinion would seem to so indicate: "[Olympic] is entitled to know what those companies ... told the Government, and this requires examination of the documents which were exchanged, or exchanged and filed in that action." "136

It seems unlikely, lowever, that Olympic Refining will be so extended. The Antitrust Civil Process Act, ${ }^{137}$ enacted in 1962, grants to the Justice Department the power to conduct certain pre-complaint discovery through the issuance of a civil investigative demand. ${ }^{138}$ The civil investigative demand describes the reason ${ }^{130}$ for the investigation and designates documentary material to be inspected. ${ }^{140}$ The Act expressly precludes third party discovery of the documents obtained through use of the civil investigative demand while the documents are in the custody of the Justice Department, ${ }^{141}$ except for those which become subject to

134 One of the three documents under seal in Olympic Refining was an outline of the Government's contentions. This document, referring to information given the Government by Standard Oil and the other defendants, specified how the Government intended to support its contentions. It is likely that such an outline would state relatively concisely what practices of the defendants were subject to antitrust prosecution. This information, probably compiled and summarized from masses of documentary detail after thousands of man hours of work, would be of great value to any treble damage plaintiff. Rather than having to winnow through a maze of detail in search of relevant information, a private plaintiff may have the path to a sucessful hitigation mapped out for him.

135 See Timberg, Recent Developments in Antitrust Consent Judgments, 10 FED. B.J. 351, 353-54 (1949).

136 Olympic Ref. Co. v. Carter, 332 F.2d at 266. (Emphasis added.) In the Government proceeding, the defendants' answers to interrogatories had not been filed with the district court. It is likely that the court of appeals, in the quoted passage, meant only to make those answers available.

13776 Stat. 548 (1962), 15 U.S.C. \$\$ 1311-1314 (Supp. V, 1964). See generally legislation, 111 U. PA, L. REv. 1021 (1963).

13876 Stat. 548 (1962), 15 U.S.C. \$ 1312 (a) (Supp. V, 1964).

13876 Stat. 549 (1962), 15 U.S.C. $\$ 1312$ (b) (1) (Supp. V, 1964).

140 76 Stat. 549 (1962), 15 U.S.C. \$ 1312 (b) (2) (Supp. V, 1964).

14176 Stat. 550 (1962), 15 U.S.C. $\$ 1313$ (c) (Supp. V, 1964), provides inter alia: "While in the possession of the custodian, no material so produced shall be available for examination, without the consent of the person who produced such material, by any individual other than a duly authorized officer, member, or employee of the Department of Justice." This section also allows the custodian (a person appointed by the Assistant Attorney General in charge of the antitrust division) to make such copies of the documents as may be required for official use. An ambiguity in the prording of $\S 1313$ (c) permits a reading that would allow third party examination of these copies; this ambiguity is supported by the above quoted portion of $\S 1313(\mathrm{c})$ and by $\S 1313(\mathrm{e})$, set forth in note 142 infra. The above quoted provision could thus be read to apply only to those materials temporarily in the cnstodian's possession; it would not, therefore, apply to copies. Such a construction seems so repugnant to the policy of the protective provision, however, that no court is likely to read the section in this manner. 
the control of a court during an antitrust proceeding. ${ }^{142}$ The civil investigative demand is likely to become the major device used by the Justice Department in its investigation of possible antitrust violations. ${ }^{143}$ A defendant, confronted with a private litigant's motion to make available information exchanged in negotiations, might be in a position to argue that the information demanded is substantially derived from that acquired by the Justice Department through use of the civil investigative demand; to allow third party discovery would be inconsistent with the disclosure restrictions of the antitrust Civil Process Act. Further, the provisions of the Publicity in Taking Evidence Act refer only to hearings before a master or examiner or to depositions. Tlose proceedings are within the trial court's purview; ${ }^{144}$ consent decree negotiations are not. The Justice Department could raise similar objections if it believes such an extension of the Olympic Refining doctrine would be detrimental to consent decree negotiations. Moreover, the Department could argue that the information given defendants at consent decree negotiations was instrumental in arriving at a consent decree; to allow discovery of this information could seriously inhibit negotiations. ${ }^{145}$. Because the consent decree is considered an important part of antitrust enforcement, the courts would no doubt give serious consideration to such contentions. If the Government were to take this position, defendants may find greater reason than before to negotiate informally rather than force the Government to obtain information through discovery not available by use of the civil investigative demand. ${ }^{146}$ Thus, Olympic Refining could encourage rather than deter negotiations.

142 Section 1313(e) provides: "Upon the completion of (1) the antitrust investigation for which any documentary material was produced under this chapter, and (2) any case or proceeding arising from such investigation, the custodian shall return to the person who produced such material (other than copies thereof made by the Department of Justice ... .) which has not passed into the control of any court or grand jury through the introduction thereof into the record of such case or proceeding."

143 See 107 Cong. Rec. 20,661-62 (1961); 111 U. PA. L. REv. 1021, 1021-24 (1963).

144 FED. R. Crv. P. 30(b), 53.

145 Consent decree negotiations are best conducted when the Government and the defendants are not reluctant to exchange information. Allowing discovery of information exchanged at negotiations would make defendants hesitant to disclose potentially detrimental information. The situation would be analogous to permitting third parties to participate in negotiations. See Timberg, Recent Developments in Antitrust Consent Judgments, 10 FED. B. J. 351, 353-54 (1949).

146 The Government, through the civil investigative demand, cannot require that which would be held to be unreasonable or privileged from disclosure if demanded by a subpoena duces tecum issued in conjunction with a grand jury investigation. 76 Stat. 549 (1962), 15 U.S.C. \& 1312(c) (Supp. V, 1964). Although not explicitly prohibited, the statute does not provide for the taking of depositions or written interrogatories. It would appear, therefore, that this type of information would have to come either through informal channels of commumication, like consent decree negotiations, or through discovery. 
When the Government chooses to litigate, the defendant's knowledge about the Government's contentions may liave to come through discovery. There would be little reason for the Government to give defendants information through an informal arrangement comparable to consent decree negotiations. Where defendants are forced to obtain all their information about the Government's case through discovery, private litigants would benefit if Olympic Refining is followed. If the Government case goes to trial only after unsuccessful consent decree negotiations, the availability to private hitigants of the Government's contentions and discovery data probably would be governed by the extent to which the defendant obtained the information through discovery rather than through negotiations.

\section{CONCLUSION}

The Justice Department's limited success with the asphalt clause demonstrates the difficulty of obtaining botli a consent decree and a section 5(a) judgment. Adequate injunctive relief generally will be the only protection afforded third parties by a consent decree. If, lowever, private litigants are given a riglit to relief for injury caused by a defendant's violation of a consent decree, the Government probably will gain an effective ally in the policing of judgments. Therein seems to lie the greatest potential for aclieving coordination between consent decrees and private actions in the enforcement of the antitrust laws.

Robert W. Stedman 